action of phosphine in man is not known. It has, however, been found to cause non-competitive inhibition of cytochrome oxidase of mitochondria in mouse liver, housefly, and granary weevil. ${ }^{5}$

Since the mortality is so high and there is no specific antidote, we suggest that a less toxic but equally effective agent should be sought to replace this lethal substance.

1 Hackenberg U. Chronic ingestion by rats of standard diet treated with aluminium phosphide. Toxicol Appl Pharmacol 1972;23:147-58.

2 Childs AF, Coates H. The toxicity of phosphorous compounds. In: Mellor's comprehensive treatise on inorganic chemistry. Vol VIII. Suppl III. The phosphoru volume. London: Longman, 1971:1438-40.

3 Wilson R, Lovejoy FH, Jaeger RJ, Landrigan PL. Acute phosphine poisoning aboard a grain freighter. $\mathcal{F} A M A 1980 ; 244: 148-50$.

4 Heyndrieckx A, Peteghem CV, Heede MV, Lauwacrt R. A double fatality with children due to fumigated wheat. European fournal of Toxicology 1976;9:113-8. Chefurka W, Kashi KP, Bond EJ. The effect of phosphine on electron transport in mitochondria. Pesticide Biochemistry and Physiology 1976;6:65-84.

(Accepted 8 fanuary 1985)

Postgraduate Institute of Medical Education and Research, Chandigarh 160012, India

SURJIT SINGH, MD, assistant professor in internal medicine

J B DILAWARI, MD, MRCP, associate professor in hepatology

R VASHIST, MD, lecturer in pathology

H S MALHOTRA, MD, senior resident in internal medicine

B K SHARMA, MD, FAMS, professor of internal medicine

Correspondence to: Dr J B Dilawari.

\section{Severe cutaneous reactions to captopril}

Captopril is an angiotensin converting enzyme inhibitor used to treat hypertension and cardiac failure. Cutaneous reactions to captopril are common, occuring in about $12 \%$ of patients treated for hypertension, ${ }^{1}$ and generally thought to be mild and self limiting they include angio-oedema, a pruritic maculopapular eruption, a rash resembling pityriasis rosea, ${ }^{1}$ mild toxic erythema, ${ }^{2}$ and exfoliative dermatitis. ${ }^{3}$ None of these reactions was confirmed by challenge. We recently saw a more serious and extensive pattern of eruption develop during treatment of cardiac failure with small doses of captopril.

\section{Case reports}

The table gives details of the four patients reported on.

Case 1-A 59 year old woman was given captopril, up to $75 \mathrm{mg}$ daily, for cardiac failure. After two weeks she developed a pruritic macular eruption, which settled without change in treatment. Four weeks later a scaling erythema that began on her hands and face led to erythroderma. Captopril was withdrawn, and after six weeks the eruption had settled. A challenge dose of captopril $12.5 \mathrm{mg}$ reproduced the eruption in four days, which resolved in two weeks. Her heart failure was subsequently controlled by enalapril.

Case 2-A 57 year old man with insulin dependent diabetes was given captopril $75 \mathrm{mg}$ daily for cardiac failure. After six weeks he developed an urticated scaling erythema of the hands and face that extended to other areas. This lasted for six weeks despite withdrawal of captopril. A challenge dose $(12.5 \mathrm{mg})$ exacerbated the eruption, which resolved in two weeks.

Case 3-An 80 year old man with cardiac failure received captopril, up to $75 \mathrm{mg}$ daily. Three weeks later he developed an eczematous eruption of the hands and arms that led to erythroderma and persisted for four weeks despite withdrawal of captopril. His other treatment was not changed. He died of uncontrollable cardiac failure shortly afterwards.

Case 4-A 63 year old man with cardiac failure was given captopril $75 \mathrm{mg}$ daily. He developed an urticated erythema four weeks later. Allopurinol, which he had taken for two years, and captopril were stopped. The eruption persisted for two weeks, and he died soon afterwards. The pattern and time course of his skin eruption strongly implicated captopril.

\section{Comment}

These cases show stages of the same eruption, characterised by an urticated erythema with eczematous features leading to erythroderma. The delayed onset, relentless progression, and intractability of the eruption after withdrawal of captopril were consistent features. A single challenge dose of $12.5 \mathrm{mg}$ reproduced the reaction. Biopsy showed acute or acute on chronic dermatitis with perivascular inflammation. Immunofluorescence studies yielded negative results.

This pattern of eruption was different from those previously described, which were thought to be pharmacological in nature, probably due to inhibition of inflammatory mediator metabolism by angiotensin converting enzyme, and were dose related. ${ }^{1}$

This new eruption seems to be a truly allergic response to captopril reproducible with one dose and not dose related. The patients had impaired renal function, but even so captopril $75 \mathrm{mg}$ daily is not a high dose, although delayed clearance may have contributed to the intractability of the eruption. The delayed pattern of onset suggests a photosensitive element, and as the patients were receiving several drugs an interaction with captopril was also possible. All these factors may have affected the final pattern of eruption, and the sulphydryl group of the captopril molecule, not present in enalapril, may have been the allergenic focus, as has been previously suggested. ${ }^{4}$

We believe that these four cases show a new, severe pattern of eruption due to captopril as used to treat cardiac failure. If the potential of angiotensin converting enzyme inhibitors is to be exploited in the next five years ${ }^{5}$ we must be sure that each new therapeutic indication is not accompanied by a new, more serious side effect.

1 Wilson JK, Hammond JJ, Kirkendall WM. The captopril induced eruption. Arch Dermatol 1980;116:902-5.

2 Kayanakis JG, Giraud P, Fauvel JM, Bonnhoure JP. Captopril eruptions. Lancet 1980 ;ii :923.

3 Solinger AM. Exfoliative dermatitis from captopril. Cutis 1982;29:473-4. 4 Gavros I, Gavros H. Captopril and enalapril. Ann Intern Med 1983;98:556.

(Accepted 7 fanuary 1985)

Department of Dermatology, University Hospital, Queen's Medical Centre, Nottingham NG7 2UH

M J GOODFIELD, MRCP, registrar

L G MILLARD, MRCP, consultant

Correspondence to: Dr M J Goodfield.

Details of four patients with skin eruption after treatment with captopril up to 75 mg daily

\begin{tabular}{|c|c|c|c|c|c|c|c|}
\hline $\begin{array}{c}\text { Age } \\
\text { (years) } \\
\text { and sex }\end{array}$ & Eruption & $\begin{array}{l}\text { Time course of } \\
\text { eruption }\end{array}$ & $\begin{array}{c}\text { Duration } \\
\text { of captopril } \\
\text { treatment }\end{array}$ & $\begin{array}{l}\text { Other drugs } \\
\text { (daily doses) }\end{array}$ & $\begin{array}{c}\text { Abnormal } \\
\underset{(\mathrm{mmol} / \mathrm{l})}{\text { biochemical results }}\end{array}$ & Result of challenge & Result of biopsy \\
\hline $59 \mathrm{~F}$ & Erythroderma & $\begin{array}{l}\text { Onset six weeks after } \\
\text { captopril started. Lasted } \\
\text { six weeks after } \\
\text { withdrawal }\end{array}$ & 4 months & $\begin{array}{l}\text { Frusemide } 120 \mathrm{mg} \\
\text { Warfarin }\end{array}$ & $\begin{array}{l}\text { Urea } 11 \cdot 3 \\
\text { Creatinine } 183\end{array}$ & $\begin{array}{l}\text { Positive (but no } \\
\text { recurrence with } \\
\text { enalapril) }\end{array}$ & $\begin{array}{l}\text { Acute on chronic dermatitis } \\
\text { with infiltrate of } \\
\text { polymorphs and } \\
\text { eosinophils. No } \\
\text { immunofluorescence }\end{array}$ \\
\hline $57 \mathrm{M}$ & Urticated erythema & $\begin{array}{l}\text { Onset six weeks after } \\
\text { captopril started. Lasted } \\
\text { six weeks after } \\
\text { withdrawal }\end{array}$ & 2 months & $\begin{array}{l}\text { Frusemide } 120 \mathrm{mg} \\
\text { Digoxin } 0.25 \mathrm{mg} \\
\text { Isosorbide } 60 \mathrm{mg} \\
\text { Insulin }\end{array}$ & $\begin{array}{l}\text { Urea } 13.8 \\
\text { Creatinine } 190\end{array}$ & Positive & $\begin{array}{l}\text { Acute or chronic dermatitis } \\
\text { with polymorphic and } \\
\text { lymphocytic infiltrate. } \\
\text { No immunofluorescence }\end{array}$ \\
\hline $80 \mathrm{M}$ & Erythroderma & $\begin{array}{l}\text { Onset three weeks after } \\
\text { captopril started. Lasted } \\
\text { four weeks after } \\
\text { withdrawal }\end{array}$ & 4 weeks & Frusemide $120 \mathrm{mg}$ & $\begin{array}{l}\text { Urea } 23 \cdot 1 \\
\text { Creatinine } 428\end{array}$ & $\begin{array}{l}\text { Patient died before } \\
\text { challenge }\end{array}$ & $\begin{array}{l}\text { Acute dermatitis with } \\
\text { perivascular eosinophilic } \\
\text { infiltrate. No } \\
\text { immunofluorescence }\end{array}$ \\
\hline $63 \mathrm{M}$ & Urticated erythema & $\begin{array}{l}\text { Onset four weeks after } \\
\text { captopril started. Lasted } \\
\text { two weeks after } \\
\text { withdrawal }\end{array}$ & 5 weeks & $\begin{array}{l}\text { Frusemide } 250 \mathrm{mg} \\
\text { Hydralazine } 75 \mathrm{mg} \\
\text { Digoxin 0.125 mg } \\
\text { Warfarin } \\
\text { Allopurinol } 200 \mathrm{mg}\end{array}$ & $\begin{array}{l}\text { Urea } 19 \cdot 3 \\
\text { Creatinine } 211\end{array}$ & $\begin{array}{l}\text { Patient died before } \\
\text { challenge }\end{array}$ & $\begin{array}{l}\text { Acute dermatitis with } \\
\text { perivascular polymorphic } \\
\text { and eosinophilic } \\
\text { infiltrate. No } \\
\text { immunofluorescence }\end{array}$ \\
\hline
\end{tabular}

